\title{
Notes on the Native History of Cuba and the Dominican Republic
}

\author{
Randle Sloan Toraño \\ University of Jaume I, Castellón, Spain \\ * Corresponding author email: randlesloan@gmail.com \\ Received: 28 December 2019 / Revised: 27 January 2020 / Accepted: 02 February 2020 / Published: 15 February 2020

\begin{abstract}
Caribbean history and ethnocultural evolution since the late nineteenth-century has been restructured to strategize a new scholarly native. This study examines how Cuba and the Dominican Republic became cultural markets for such trend. It also reviews the hypothetical extinction of the Caribbean naturals as it potentialized a highly commercialized era as theorists developed unique tools to implement an academic discourse irrelevant to Caribbean natives' origins, cultures and fate. The cultural market trends were so far-reaching and successful that there is a need to assess pre-European native Caribbean history away from the sought-after taino market modeled after Constantine Samuel Rafinesque since 1836 . Consequently, by the mid twentieth century a critical separation from traditional native Caribbean ethnohistory was well established within a suppositional trend inconsequential to original native biological evolution, language and diversity. This study analyses early ethnopolitical native contacts as tribal independencies interacted before and after discovery. Relevant historical facts originated from national archives and critical older books.
\end{abstract}

Keywords: Native languages, tribal diversity, cultural markets trends, native biological evolution.

\section{Introduction}

Caribbean native history and ethnohistory advanced for nearly two centuries while distancing itself from the classic chroniclers' original data. Consequently, the standardization of Caribbean natives steered away from tribal designation as natives' biological evolution and history attracted public attention. The standardization of the taino culture as a practice substituted native Caribbean cultures as a community of scholars dominated the subject. In order to restore the natural evolution of a legitimate native history some research questions, need clarifications, for example:

- How do new terms and terminologies affect our current perspective on Caribbean native's antiquity?

- How do we perceive Caribbean natives' survival [based on new terminology and not legacy]?

- Have Caribbean nativists' become victims of scholarly standardization?

- Does Caribbean native biological evolution align with concepts of cultural heritage and ancestry?

- Are Caribbean native DNA results too limited in scope or too isolated geographically?

To answer these and other questions let's examine how a cultural market trend was engineered to move the taino from theory, to trend and to history by a scholarly community (Sloan, 2018). Subsequently we analyze the historical foundation, ethnohistorical data and chroniclers' intentions, languages, racial miscegenation and the issues of scholarly boundaries reinventing a pre-European-contact native society. Extinction as the basis of standardization simplified the adoption of a new native terminology discussion. The consensus was that natives had disappeared, had been exterminated and so little survived that a new scientific native model found a conventional space to fill. But, had the original natives vanished? And, what if they had not vanished? In that sense extinction as a basis for theorization simplified the adoption of a standardized 
Notes on the Native History of Cuba and the Dominican Republic

native terminology away from history. Even if all biological and cultural traces had disappeared why did a scholarly discourse need a new standardized native.

Douglas Taylor and Irving Rouse in the mid twentieth century strategized the deep roots of the imaginary taino generated by Constantine Sammuel Rafinesque. The word taino is not an ancient Caribbean denomination representative of native tribes, nations, or language, it is a creation of C S Rafinesque in 1836. We need to understand that the word taino is strictly a scholarly standardization unrelated to ancestors. Yet, even in the twenty-first century researchers continue to advocate the historical realness of tainos, (Ozuna, 2018); (Morejón, 2018); (Tracy, 2018); (Burley, 2017); (Ostapkowicz, 2018).

In (Taylor \& Rouse, 1955) they successfully fit the taino into a historical chronology by assuming deities within a Taino culture developed from the Igneri in the Greater Antilles. Clearly such assessment has little if anything to do with ethnohistory or Caribbean history. First, we need to separate fact history from a multidisciplinary scientific trend. To do so within the era let's examine Edward Hallett Carr's (1961) view of history. Carr views the historian and the facts of history as necessary to one another. Carr further describes how the historian without his facts is rootless and futile; the facts without the historian are dead and meaningless. For (Taylor \& Rouse, 1955) historical facts appear secondary to their archeological evaluation of artifacts identification within the imaginary culture they professed.

As historians we are oriented to interact and understand facts. At best, the discussion between (Taylor and Rouse, 1955) is an archeological adopted tendency. They acknowledge a problem: "Unfortunately, the extant Taino vocabulary is too meagre, the transcription too erratic, and the given meanings too uncertain to offer much help in this respect." Taylor and Rouse $(1955,112)$ state that: "The two sets of evidence are contradictory, and so we are faced with a dilemma." Such linguistic persistence was futile, plain and simple, Taino was never a language. Over the decades such explorations went out of control trying to find a linguistic fit, [and a Taino pottery narrative to answer question of a non-existing native]. In this sense nativists, students and younger researchers become victims of a scholarly cultural market boom born from necessities and not from legacy. This sample represents a clear separation between theoretical terminological standardization and ancestry. Why was so much credibility given to a fictional character? When a scientific argument for the sake of attributing hands and faces to artifacts in the Greater Caribbean depends on theories based on a market trends, it fails to understand the artisans and the people who worship wood and stone as a symbol of their own culture.

The conflicting issues of the new standardization built over two centuries when contrasted to the Caribbean native history of pre-Columbian days of the people who beyond shaping and worshiping wood and stone artefacts left countless clues as to whom they were, is such, that now touches the minds and souls of people in a brand-new light. To avoid further confusion, we must keep in mind that the Caribbean native origins, languages, biological evolution and the surviving Caribbean native ancestry are historical and cultural realities unrelated to the word taino. As the taino standardization has failed its intended purpose new views on historical based geographical native denominations, their implications to native independencies and native interconnectivities are yet to be proposed by researchers. Current researchers tend to refer to native Caribbean tribal people as Indians, indios, indigenas or a derivate of such nature it's essential to provide proper denominations.

\subsection{A note on nineteenth-century Cuba}

José Ignacio Rodríguez (1874) reviews the legendary José de la Luz y Caballero, the director of La Sociedad Patriótica and La Real Sociedad Económica de la Habana, Cuba. In 1842 de la Luz was ill and recovering when he received a letter from David Turnbull the British ambassador to Cuba also a member of the Sociedad Patriótica. David Turnbull was being expelled from the society for his emancipation ideals. Rodríguez cites Turbull's letter: “( ...) human liberty and individual rights, without race or skin color distinction, are more respected in the UK than in any other country of the world." (1874, p. 126-127). Race in Cuba since the 
Randle Sloan Torano, Adv. J Social Sci.; Vol. 7, Issue 1, pp: 14-26, 2020

eighteenth-century had undergone some distinctive changes captured in the daily life of people. David Turnbull describes ethnic details in a census acquired from the Patriotic Society of Habana: Turnbull (1840, p. 556) states that, the whites, or blancos, are either proprietors of the soil or tradesmen, or the paid dependants of either and their families. The agregados are also considered of pure European descent, holding the station of cottiers on the plantations, and contributing a certain portion of labour in place of rent. The pardos are free people of mixed race, not strictly white and not darker in complexion than the mulatto.

These racial classifications were common in Cuba, the Dominican Republic and Puerto Rico within their own particularities and legacies. In the Archivo Nacional de Puerto Rico (ANPR), census box of Utuado dated 1849 miscellanies file, it contained two main collections the, Registro de Jornaleros (1847) and the Padre de familia (1849). Findings indicate that pardos was a common ethnic denominator. Within the Registro de jornaleros we examined the following racial descriptions: Europeos, blancos, mulato, pardos and trigueños. In addition we found other racial classifications within a total of 342 cases examined under the Padres de familia file, for example, case \#50 Lazaro Castro was identified as (palido amulatado), case \#51 as (palido blanco), case \#59 as (color moreno), case \#66 as (trigueño claro), case \#103 as (amulatado), case \#186 as (palido). The words indio or taino were not found within the archive files reviewed. Turnbull, mixed race not strictly white, is open to interpretations, yet Turnbull himself recalls of the population resemblance of Cuba and the Dominican Republic of his days. What then is the ethnic consequence and significance of a contemporary racial diversity regarding native survival. Let's try to understand how past trends become a cultural market myth across decades.

Mark R. Harrington (1921, p. 135) remarks on the work of Alfredo Zayas y Alfonso and makes the following comments about Zayas All through the work, however, it is noticeable that the use of the word "Taino" as a general term for the predominant class of natives of the Greater Antilles, whose language Zayas is presenting, is studiously avoided. As in any statement that these people may be affiliated with the Arawak linguistic family.

Harrington (1921, p. 136) still provides further insight to the confusion of the native Cuban dialects in a statement linking Brinton to the taino language based on a study of the Arawak language as spoken by tribesmen of British Guiana and Dutch Guiana. Harrington in his desire to fit his taino to the native languages of Cuba made an enormous mistake in assuming that Brinton's work identified the taino as an Arawak, beyond a shadow of a doubt. Daniel Garrison Brinton (1871) clearly articulated that it was Rafinesque who christened the "Taino" language, and further states that Rafinesque and Jeogor von Sivors have made vocabularies of it, but the former is so uncritical, and the latter is so superficial a manner, that they are worth than useless. Brinton was the first scientist to object to the imposition of the term taino. Yet, Harrington cites Brinton to promote a fictional construction of a Cuban native as he ignores Zayas.

Alfredo Zayas y Alfonso (1861-1934) was a lawyer, prosecutor, judge, mayor of Havana, vice president and president of Cuba. Zayas was the first to discard the taino in his country and had a great deal of responsibility in doing so. His father was José Maria Zayas who along with Antonio Bachiller y Morales were entrusted in 1862 with the care of papers, manuscripts and printings of José de la Luz y Caballero. De la Luz delegated José Bruzon and Jesus Benigno Galvez to assist his friends. Bruzon and Galvez eventually assisted Alfredo Zayas y Alfonzo who in 1890 published some of these documents carrying out the duties assigned to his father and Bachiller y Morales three decades after de la Luz death. In this sense Zayas represents responsibility and dedication to family and Cuban nationhood. By the time Harrington met Zayas it is likely that Zayas had read and understood José Fornaris poem dedicated to de la Luz, published in El Progreso on June 29, 1862, were a single line reads: "Never did I dreamt my voice would ever reach you. I only sang the siboneya race one as poor as me." (Rodrigues, 1874, p. 315).

Harrington was digging for artefacts to conceptualize a terminology he valued. The question is: did he understand Cuba? José de la luz y Caballero, José María Zayas, Antonio Bachiller y Morales and Alfredo Zayas y Alfonso are but a limited few in Cuban history that in the nineteenth century were deeply rooted in patriotism and tradition. From the ideological wealth of these men arose one preoccupation that was readily identified. For example, this sentence from the written work of (de la Luz 1890, p. 69) a strict 
Notes on the Native History of Cuba and the Dominican Republic

Christian: "The language of civilization, mixed with that of the barbarians, our fathers. Knew to soften, refine and so to speak spiritualize their rude languages."

The barbarians our fathers as José de la Luz y caballero called his ancestors was indeed a preoccupation as Bachiller y Morales opted for a taino interpretation. José Fornaris y Luque by 1850-1855 in "Canto del Siboney" made of the Siboney a movement, siboneismo. Juan Cristóbal Nápoles Fajardo known as "el Cucalambé" wrote a love and tragedy poem in 1856, La luz de Yara, the story of Hatuey and Guarina, a Quisqueyan cacique who escaped Spaniards into Cuba to eventually burn at Yara.

Let's examine a sequence of events, Fornaris and Cucalambé in their symbolism and siboneismo moved ideology from poetry into the field of liberation. In 1851 Fornaris wrote the first Bayamesa a love story. That year Pedro Felipe Figueredo y Cisneros formed the Sociedad Filarmónica with Carlos Manuel de Cespedes to partner with local intellectuals including José Clemente Zenea and José Fornaris. Eventually by 1867 , Figueredo formed the revolutionary committee of Bayamo and during that time wrote another Bayamesa which in time become the national anthem of Cuba. Figueredo a Cuban revolutionary leader was captured by Spaniards on August 12, 1870 and executed by a firing squad five days later. Alfredo Zayas y Alfonso was influenced by Cuban nationalism and was aware of the taino adopted by (Bachiller y Morales 1883). The question is: did Harrington understand the Siboney symbolism of the Zayas generation and their cubanidad rooted within that native ancestry.

\subsection{Comments on Dominican Republic}

In the Dominican Republic Roberto Cassá is one of the leading scientific researchers. In (Cassá, 1974, p. $16,179)$ in a few lines defines his objectives and rationale: "The Taino culture, object of this essay, comprised the great majority of Aboriginal settlers of the Antilles, in the historical period before the arrival of the Europeans." Cassá continue to describe the ciguayos, macorixes and tainos as having different languages and features as inferred from historical data.

Roberto Cassá (1974) groups authentic tribal nations [macorixes and ciguayos] in the Dominican Republic and guanahatabeyes and ciboneyes (siboneis) of Cuba] to a terminological symbol reasoning that such generalization is inferred in historical data. Such theorization is again a departure from history. By 1974 the taino scholarly community was inseparable from the Dominican scientific culture scrutinizing Caribbean natives.

Whereas the term had been widely objected by, (Daniel Garrison Brinton, 1871; Cayetano Coll y Tosté, 1907; Alfredo Zayas y Alfonso, 1914; Carl Ortwin Sauer, 1966), Cassá in his study references Coll y Tosté and Sauer while failing to understand their objections. In 1974 the Rafinesque 1836 taino was not an issue of concern and little attention had been given to the credibility of the new terminology. 1974 became the golden age of the taino cultural market as the commercialization was absolute by the end of the twentiethcentury. During this period countless young nativist and scholars fell victim to the scholarly diffusion of an academic fictional idol. Genaro Rodrigues Morel et al. (2016: 142) decades later states: "The tainos constituted the Antillean farmer group with the greatest cultural development that the Spanish conquerors found in Cuba, Santo Domingo and Puerto Rico.” In (Rodrigues Morel et al., 2016, p. 146) they state that: "The language of the Tainos and possibly, despite their differences, with that of the macorijes and ciguayos, came from a common South American trunk. They were forms of the Arawak language, Arawako, or Arauco, if we consider the different spellings of it. That language is still associated today with the lokono and arawak that is spoken in the Guianas." Rodrigues Morel et al (2016) places a non-existing taino language among several native tribes as, macorixes, macorijes and ciguayos in South America. In the twenty-first century it is assumed factual that the taino people and their language in Cuba, Santo Domingo and Puerto Rico were real. To understand Rodrigues Morel et al., we need to examine the experts they trusted Manuel Alvarez Nazario and J J Arrom. José Juan Arrom Gonzalez was a taino theorist who diffused successfully the term for decades. 


\subsection{Strategizing a Caribbean native fiction}

Taylor and Rouse (1955) proposed that the taino developed from the igneri within the Greater Antilles but shared into a common Arawakan linguistic trunk. Mark Harrington (1921) theorizes that the taino language had roots in British Guiana and Dutch Guiana proposing Brinton (1871) as his expert. Even though (Rodrigues Morel et al. 2016) counts on Manuel Alvarez Nazario and José Juan Arrom as their linguistic experts they believe the merits are correct. Over a century goes by as, (Bachiller y Morales, 1883; Harrington 1921; Taylor and Rouse, 1955; Arrom, 1967; Rodrigues et al., 2016) are all in agreement of the existence of a taino language, a taino culture and a taino native. During the late twentieth and early twentieth century the taino terminological standardization continued to grow yet, -there is no historical or ancestral truth the entire science is based on a scholarly discourse and a cultural market trend.

Let's review José Juan Arrom as he introduces his study on Ramón Pané as he describes how, "few nations have had as cruel a destiny as that of the smiling Tainos who greeted Columbus and his people in 1492 on the pleasant Antillean beaches." Arrom (1967, p. 378) continues to discuss unjust wars. With the belief that in a few years, "few survivors had to accept the new order of life imposed by the victors." The dialogue continues as (Arrom, 1967, p. 393) ends his theory after distributing the taino across the Caribbean with this thought, "seen this way, the myth has a precise meaning within the environment in which the Taino lived and reflects its character and worldview" and continues to debate mythology as factors that happily harmonize in the Antilles as, land, sea and man.

Arrom's theory groups native island inhabitants of distinct tribal origins and independent nations under a cultural standardization. Arrom finds harmony in the geographical characteristics of the Antilles, as land, sea and man emerge under a singular tribal nation of a smiling Taino. By 1967 such harmony and standardization were unquestionable as opposing views were simply ignoring.

Six decades earlier Edward Gaylord Bourne had written about Pané and tainos. Bourne (1906: 3,4) argued that Columbus having commissioned Friar Ramón Pané with the duty to, "collect all their ceremonies and antiquities (...) of the long since extinct Tainos the aboriginals of Haity." and the native's way of life between 1493 and 1496, had become a pioneer in American Anthropology. Bourne based his conclusion on the works of Ramón Pané, Ferdinand Columbus's biography of his father with the collaboration of Bartolomé de las Casas as published in the surviving text printed in Venice in 1571 authored by Alfonso Ulloa. Bourne associates Panés, las casas, Christopher Columbus and Ferdinand Columbus with the Tainos as the aboriginal habitants of Hayti. In this scenario (Bourne, 1906, p. 4) adds a term not contained within any of the documents he cites, "of the long since extinct Tainos, the aboriginal inhabitants of Hayti."

Arrom 1967 and Bourne 1906 share a scientific interest directly diffusing an extinct taino native away from the original intentions of the authors they cite. Additionally, Bourne (1906, p. 9-10) provides a: "List of modern works dealing directly with the treatise of Ramon Pané or particularly serviceable in the study of it." Bourne lists a total of thirteen names he considered of importance. Of the thirteen names cited only four are considered relevant to the fictional evolution of the taino; (Antonio Bachiller y Morales, 1883; Karl von Martius, 1867; Oscar Peschel, 1876; C. S. Rafinesque, 1836). Also, listed is Leon Duoay (1891) whom in his, Native American etymological studies (grammar dictionary) makes no mention of tainos, referring only to Quisqueya, Haiti, Haitien, Lucayes and yucayos. Of the thirteen cited in (Bourne, 1906) Bachiller y Morales is the only non-European. This was expected as the incubation phase of the taino (1836-1900) lined the way for a cultural market trend in the twentieth century (Sloan, 2018). Bachiller y Morales and Arrom were two successful Cuban researchers who diffused the taino as a Caribbean native following a trend that would prove to be inconsistent with history. In Latin America before (Rafinesque, 1836) there were no references of a taino tribe, taino nation or taino language. The first Caribbean diffuser was (Bachiller y Morales, 1883) who found his taino not in his own backyard but in the work of Rafinesque and (von Martius, 1867) in Germany. 
Notes on the Native History of Cuba and the Dominican Republic

\section{Problematic issues}

Since 1836 original classic documents have been cited, footnoted and translated away from the classic authors intentions to promote the terminological standardization of a taino as a Caribbean native. Subsequently, Cuban, Dominican, Haitian, Bahamian and Puerto Rican natives became a cultural market where native independence and diversity were substituted by a standardized idol. By pinpointing specific historical periods, the taino standardized market trend can be identified away from traditional Cuban and Dominican native history. [Since DNA provides natural origin, biological ethnic percentages and clarifies results concerning human evolution a fact history analysis aids in providing a more effective interpretation of theories]. This study analyses issues of pre-contact and post-contact diversity and independent tribal nation's leading to a Caribbean native biological evolution embedded through the centuries in a philosophical debate. This evolution fails in significance if the Caribbean tribal diversity is associated with any standardized taino terminology. Caribbean native's history makes way for a cultural market trend as the taino fixation serves as evidence to support a terminological Standardization. Consequently, the fact or truth tribal independent history of a diverse Caribbean native and its biological evolution exceeding five centuries is compromised.

\section{Literature review}

The following section assist in understanding the common aspects of native history and languages before discovery within our region of study. The concepts of tribal generalizations fail to understand tribal nations independencies, ethnic diversities and historical indicators.

Hernando Escalante de Fontaneda [1566] in the, Archivo General de Indias (AGI), Patronato Real 18, Numero 5, the relation of all caciques of Florida; Buckingham Smith, 1854; Juan Bautizta Muñoz, 1783, serves to history. Escalante de Fontaneda was a Spanish castaway at the age of thirteen was a captured by the son of Senquene, the powerful cacique Carlos around 1549. Escalante de Fontaneda after his seventeen years of captivity wrote his memoir followed by a memorandum by Juan Bautista Muñoz in the eighteenscentury and published in 1793. Escalante states that Carlos was a lord of fifty tribes setting a scenario for a fundamental native history of Florida and its connection to Cuba and the Caribbean. Escalante refers to Carlos nation as a province which is relevant to our subject; as it sets a background to the identification of native tribes within a province or a nation. As we examine tribal dialects and native nations of Florida, we find that some independent native cultures shared linguistics features not always with the same meaning. For example, Carlos a Spanish name corruption possibly adapted from Caalus and more in line with the Calusa tribe, or Calos as spelled by René de Goulaine de Laudonnière and M Basanier (1586, p. 72-73) has tree variables or more when only considering English, French and Spanish grammatical versions.

Escalante's memoir dated around [1575] as noted in (Muñoz, 1793) was poorly written. So, accordingly we are following in the examination of some limited issues. In Buckingham Smith (1854, p. 17) the River Jordan or the fountain of youth searched by Ponce de Léon had some truth as described in Escalante's words as he refers to Cuban natives in Florida before Columbus, in regards to the Cuban natives the following description is made, "so earnestly did they engage in the pursuit, that there remains not a river, nor a brook, in all Florida, not even lakes and ponds, in which, they did not bathe; and to this day thy persist in seeking the water, and never are satisfied." The story goes that earlier in time Cuban natives entered the province of Carlos in search of the fountain of youth and were stopped by Senquene, Carlos father. Senquene settled the visitors where they remained likely beyond Escalante's time.

Escalante was rescued in Florida by Pedro Menéndez de Avilés who became the first governor of Florida and founder of San Agustín. That historical chapter of Florida is not only full of intrigue but sets deep roots as to the first long-term European settlement in the United States. The Escalante experience is closely dated to the published works of Álvar Núñez Cabeza de Vaca [1542, 1555] again helpful as both men interacted with natives in Florida on first-hand basis. Pedro de Buztintxuri was also a shipwreck in Florida who lived among the Ais for nineteen years until he was captured by the French and shipped to France. Bustintxury 
Randle Sloan Torano, Adv. J Social Sci.; Vol. 7, Issue 1, pp: 14-26, 2020

(Busitincury) was taken to France by Jacques Ribault from whom he eventually escaped making it to Spain, Eugene Lyon (1973, p. 258). In Spain he was received by Phillip II who was so impressed with his accounts that Busitincury was commissioned as Indian Ambassador assisting Menéndez. In Florida, Bustincury had a son with the sister of an Ais cacique. Escalante, Cabeza Vaca and Busitincury are original shipwreck survivors confirming the history of Florida as their experiences and publications provide a glance into native American prehistory. Cabeza de Vaca ended in Mexico seven years after entering Clearwater and Tampa. Cabeza de Vaca and his expedition were after gold and the fountain of youth which was acknowledged by Escalante. Escalante as a young man connects the tales of the fountain of youth to Juan Ponce de León in Florida as he also knew of the ancient travels by Cuban natives before Columbus settling in Florida.

In Escalante's memoirs Carlos nation is composed of some fifty tribes listed by names, -the number of tribes by itself characterizes a territorial national unit occupying an undetermined expanse of the total geographical area of Florida today. In order to characterize tribal independencies, we will review word composition in order to compare grammatical commonalities to distinct geographical areas. For example, Guale a native nation (Georgia), one where Father Sedeño, brother Domingo and brother Baez translated the catechism in the guale language in 1568. In (Smith, 1857, p. 46) the author presents a Spanish sworn declaration in Cuba by Vasco Porcallo de Figueroa on February 28, 1522, in front of magistrates Marcelo de Villalobos and Juan Ortiz de Matienzo at the age of 28. He was asked if he had cut off the testicles of some Indians to which he replied, he had in order to stop them from eating dirt which had killed $2 / 3$ of all natives in the provinces of Comaguey and Guamahaya as other guaymaros kept eating dirt and; "(...) because by no means he could end such a serious damage, he made punishment with which he prevented it largely." No harm came to Porcallo as the magistrates signed off on March 13, 1522. Comaguey refers to Camagüey and Guamahaya in capital letters refers to a province whereas guaymaros in small caps is likely a tribal denomination. In the following section the prefix gua is selected for a brief review of common traits, linguistic composition and how native independences were created.

\subsection{Linguistics, periodization, tribal name formation and their cultural impact}

As we examine geographical names, proper names, nouns, designations and generalities, we notice a linguistic connection not only between Cuba and the Dominican Republic, but to other American geographies. Escalante was a witness to historical travels between cuban natives and Florida natives as these tribal encounters had become a practice before his time. Carlos father was likely over fifty years of age when Escalante arrived in Florida decades earlier Ponce de Leon had set out to find the Fountain of Youth based on information obtained from Cuban natives who had already encountered the Calusa's and other tribal nations in the continent. Escalante, Cabeza de Vaca and Pané add a historical and anthropological dimension to Caribbean prehistory native travels, exploration and languages as they explained tribal traditions, national diversities and linguistics with some common elements.

Let's take a closer look at the prefix gua as applied in name creation which semantic is not a corruption from a-gua in Spanish. For example, gua-ti-aos we are brothers or friends, gua-i-maros, gua-na-jos, gua-le, gua-ca$t a$, are, clans or native tribes, Gua-ya-ma a town in Puerto Rico, gua-u-ravo a river, Gua-cana-gari and Gua-rionex caciques of Hispaniola. Gua-ru-gunve weeping town, Gua-saca-es-gui river of canes were Escalante says pearls are to be found in oysters. Gua-mi-qui-na an exonym, assigned by natives to Christopher Columbus, Gua-y-qui-ries a tribe of the Orinoco. Gua-ru-gun-ve village of weeping, Gua-va-ca-esgui a river of reeds, Guari-ma, Hatuey's woman. Gua-icau-anu a tribesman from Nuhuirei who accompanied Pané as an interpreter to the nation of Guarinex. Gua-y-coas a single or double pointed wooden tip arrow used by the Aruac of Venezuela. Additionally, other grammatical aplications of gua, in our sample of name formation apply, for example, Ma-gua-na the cacicazgo of Caonabo and Anacaona, I-gua-na-mo-ta daughter of Anacoana, ni-gua a riber, gua-na-ga island near the coast of Honduras, Moquetauri Gua-ya-ba first lord of Coaibai where the dead wander, or commonly known as a fruit. Gua-mo-re-te principle chief owner of the Cemi Corocote, Gua-taba-nex owner of Corocote after the death of Guamorete the cacique of jaca-gua. Ja-gua a cacique under Carlos, 
Notes on the Native History of Cuba and the Dominican Republic

Ja-gua native tribe of the Putumayo, Ja-gua the lower part of a branch of the royal palm used to cover bohios. Ve-ra-gua coast of great riches sailed by Columbus in his fourth voyage Costa Rica, Nicaragua and Panama home to the Coclé culture of the charotegas, Ci-gua-re a kingdom to the northwest of Veragua rich in gold. Brinton (1871: 2) lists twenty Arawak alphabet letters including a, $g$ and $u$. Brinton believes that like most Indians the name formation is in the abstract connected to a person or thing. Things as implied by Brinton in our semantical formations generally is consistent within a form of geographical, natural environment, family or traditional situation. Brinton (1871, p. 11) also describes how he studied the universal language of Haiti and the high macorix de arriba and the low Macorix de abajo to compare the common language spoken in the Greater Antilles and Bahamas to that of the Guianas. Brinton considered $g$ and $j$ as aspired guttural which is fitting as they may be interchangeable considering some level of Spanish corruption. We further examined Brinton word formation with the prefix gua and found eight such words: Guaca, Guacabina, Guacamayo, Guanara, Guanin, Guaoxeri, Guatio, Guaizas. These words serve to illustrate meaning but formation and their close relationship to other American regions. León Douay (1891, p. 17) identifies guaca as the devil in the Darien language; in Haitian guaca is a god supreme, as gua according to (Douay 1891, p. 29) in Haitian signifies, this one. In the taino language proposed by (Taylor \& Rouse 1955, p. 108) gua means, we.

Escalante, Cabeza de Vaca and Pané provide valuable fifteenth and sixteenth-century original terms based on personal experience even when considering that documents, original letters and recounting of the stories were influenced by some sort of Spanish language corruption. During the fifteenth and sixteenth century provincial dialects in Spain were common and by extension to America. In addition to Iberian dialect, Latin was commonly used by monks, friars and scribes. So, these grammatical considerations and the understanding of the native mind brings us closer to grasp the meaning of designations and name formation. For example, let's how names develop a Tejas tribe becomes (Texas), the chief of Aquixo becomes (Arkansas), in Choctaw, okla means red and humma means people eventually becoming Oklahoma, Carlos, Calos, Caalus, the chief of the Calusa tribe, etc.

The chroniclers, explorers, friars and shipwreck survivors analyzed in this study documented early accounts of native tribes, cultures and languages within specific circumstances of geographical spaces representing particularities in a holistic way. The nineteenth-century Cuban and Dominican authors inherited the fact history of their natives alongside the general misapprehension of the veracity of their ancestral truth before the native standardization was embedded. In this sense let's examine some basic concepts leading to tribal name formation. John R. Swanton (1905, p. 663), tells us that a clan develops its names from animal, plants and other objects also to include personal names. Adding that the overall totem enhances name formation when including natural or unnatural realms. Lewis Henry Morgan (1877, p. 103) discusses how tribes are formed, "Each tribe was individualized by a name, a separate dialect, a supreme government, and the possession of a territory which it occupied and defended as its own. (...) Each tribe, therefore, are natural growth through the separation of the same people in their area of occupation, followed by the divergence of speech, segmentation and independence."

Considering Morgan tribal formation and Swanton definitions let's reexamine some of the authors discussed. In Rafinesque after describing how he constructs languages from fragments he claims to have succeeded with the taino. Rafinesque adds to his list of successes the Cahiri of Trinidad, the Talega, the Apalachi of North America, the Chantal of Central America, the Colla of Peru, and the Séké of old Chili, (Chile) and follows; "Whereby I shall draw some happy conclusions." Rafinesque (1836, p. 31) goes on to say that, "some have declared America, a red, beardless, naked and barbarous race, or a particular species of men." He understood that America was composed of distinct nations and tribes, some as civilized as Spaniards led by Columbus others barbarous, but not entirely savage.

Morgan and Swanton are in line with Rafinesque American theory. Yet, Rafinesque work for over a hundred years served as a guideline to Haitian natives' studies as Caribbean scholars standardized the taino across the Caribbean; (Taylor \& Rouse, 1955) postulated a homegrown taino; (Arrom, 1967) postulated the smiling 
Randle Sloan Torano, Adv. J Social Sci.; Vol. 7, Issue 1, pp: 14-26, 2020

tainos; and, (Cassá, 1974) fits a taino culture amid other ancient cultures. Meanwhile tainan theorists since 1955 have generated an original taino standardization to enhance cultural market needs fitting to trends.

\section{Discussion}

The anthropological discourse based on historical data as discussed comes about from deeply rooted issues and options. Franz Boas (1938, p. 4) reminds us of three major problems in anthropology:

1, The reconstruction of history. 2, The phenomenon of historical types and their sequences. 3, The dynamics of changes. Boas (1938, p. 1): "Among illiterate peoples the dynamic processes that shape history must be studied mainly by observation of the living generation." In this sense a cultural problem exists when the living generation struggles with extinction as their own ancestral legacy was substituted by a terminological standardization away from tribal identity, language and origin as discussed. In (Muñoz, 1793, p.11) we find a reliable source of how American natives were viewed. Muñoz referred to natives as barbarians living in misery with little to worry. And continues to describe that every family, tribe or small nation was confined to their territory along their ignorance, indolence and laziness. Further complains of their poor language, gods and superstitions.

Clearly the western philosophy in (Muñoz, 1793) associated Native Americans with barbarism, indolence and laziness highlighting a sentiment shared by many authors throughout history. Whereas the anthropological discourse of (Muñoz, 1793) is arguably deficient. His understanding of family, tribe and small nation notion tied to geography, language and spiritual life is accurate. Muñoz quote has two concepts; first, natives become vulnerable to western thinking; second, the idea of native homeland, ethnicities and spiritualism clearly suggest tribal independences. It is clearly implied in the dialogues of (Muñoz, 1793; Morgan, 1877; Rafinesque, 1836) that tribes, nations, languages and territories were common traits for the formation of natives' own distinctiveness. Whereas spiritual life adds a dimension to tribal life the question is has this issue been adequately resolved? On January 26, 2020 this author asked Edward Clown a grandson of (Tasunke Witko) Crazy Horse, in the presence of (William Matson, 2016) how would you in a few words describe the Lakota people and he replied, "Spiritual people will never be defeated."

Lewis Henry Morgan (1877, p. 103) discusses tribal formation as a natural of people, skills, language, segmentation and independence. Noticeably these common traits, national distinctiveness and name formation existed in the Caribbean before the first European contact. Consequently, concepts of natural growth mixed with the idea of native extermination facilitated a standardized terminology.

Antonio Bachiller y Morales (1883, p. 231) tells us that Camagüey had a population of Spaniards in 1538 of between 19-20 men, and states that: "What was the future of the people the "Camagüeyanos" is not the subject of this book." What we need to understand about Camagüey is that even Bachiller and Morales must have had some doubts. Did Antonio Bachiller and Morales think that Camagüeyanos was a native denomination perhaps consonant with the declaration of Vasco Porcallo de Figueroa. In the 1522 Porcallo declaration Comaguey implies the province of Camagüey of today. Or, is it an early Spanish corruption of Co-ma-gua-y or Ca-ma-gua-y or some other distinctive and grammatically incorrect native tribal name? Esteban Pichardo (1836, p. 50) defines Camagüeyano as; "The person or natural thing belonging to the ancient Indian province of Camagüey where today the city of Porto Principe is located." Pichardo was cited by (Brinton 1871, p. 11) and both researchers agreed in the use of thing in the formulation of original tribal names. Whereas Brinton only listed eight words with the prefix gua in his vocabulary of the Caribbean words earlier described in (Brinton 1871, p.15) he lists as a tribe the well-known Guanahataneyes or Guanahatabibes another sample of linguistic correspondence. It should be noted that a linguistic corruption is a grammatical error which in no way invalidates the significance of an original tribal denomination. Fernando Ortiz (1940) translates ci-gua to mean stone, gua-na, palm (singular) and gua-na-0, palms (plural), for Ortiz the Cuban native tribe is guanajabibes could it be (palm-jabibes). 
Notes on the Native History of Cuba and the Dominican Republic

\subsection{Precision within an imprecise premise}

Alauhuiku, Alau-bui-ku according to (Reichel-Dolmatoff, 1960) is the name of a great hero, the Alauhuiku Alau-bui-ku, Alau, the hero bui, a high level, ku or ukku, the heart of the tribe, our family. Arrom Unbuirey could well say, a king in Spanish related to a high level, that is, a -hui-king yet the composition is highly corrupted and perhaps the reason he did not follow up. In (Douay, 1891, p. 30) Huiou in Haitian means the sun, in Mayan ku is god and kin sun. In the Popol Vuh, the only god was, Kunab Ku, the father and Itzamna the son. The people of Nu-hui-rey is referred by (Bourne, 1906, p. 28) as a bilingual tribe in Hispaniola.

Hernán Colón, Reichel-Dolmatoff and Arrom contribute to a composition that encloses an undeniable consonance. In Alcide D'orbigny (1839, p. 389) the author presents the Huiliches of the Auca or Araucana nation, Hui-li-ches (men of the south) bui-li of the south, ches men, Picunches are (men of the north). In (D`orbigny, 1838, p. 391) the author presents the Huinca of Patagonia and says that the Puelches, are men of the east. D'orbigny in his list of names indicates that words are so confusing by their American synonyms that determining the nations of the simple tribes is difficult. As we examine the Huinca and the hui-li of D'orbigny the Unhuirey of Arrom, could mean "a king man" and ultimately, of high rank or high level. When considering that within a tribe there are clans, bands, families and even rogues with their own traits, denominations, language formation and territories native independences become endless. Brinton had stated that Huiho Hui-ho was height or high up. Brinton discussed Arawanilli is possibly derived from areaua. The great hero Alauhuiku of Reichel-Dolmatoff and Brinton's Arawanilli may well hold the key to the root name Arawak, arahuaco, arauco.

\subsection{A further note on native diversity}

Baron M. Emile Nau ([1855], 1894, p. 62) discusses languages and races of the ancient cultures of Haiti. Making references to the different idioms even within the same population. Nau also believed that at the time of discovery there were races of different kinds and of different languages living in Haiti.

In José Joaquín Pérez $(1877$, p. 16) in the prologue to Apolinar Tejera Penson writes, "Above all some merit must have, even for its eminently national character, at least because they form a bouquet of beautiful quisqueyan flowers, fragrant and yes where there is nothing exotic."

The Tejera family followed the national Dominican tradition of the Quisqueya land they loved. The same love of land, family and tradition we examined earlier in Cuba, are also common in Puerto Rico.

Emilio Tejera Bonetti (1977, p. 1193) following his own fathers' steps (Emiliano Tejera Penson 1935) cited Pablo Morales Pérez (1948): “(...) it is the biggest ethnological mistake to call Tainos the arauco.”

To finalize this study rather, than discussing large numbers of DNA studies we are concentrating with just two results for Cuba. The samples are clear to understand the concepts of extinction and that of Caribbean native biological evolution and Caribbean native biological survival over centuries. In Cuba (Gonzalez et al., 1976, p. 585) understood that the pre-contact native societies were, "completely exterminated (...) The contribution, therefore, of the Indian population to the Cuban gene pool is negligible, so that the actual gene pool consists only of African and European genes."

In just forty years since Gonzalez et al., DNA results would prove otherwise in Beatriz Marcheco-Teruel et al., (2014). That scenario is also true in Puerto Rico and the Dominican Republic. The mistake in (Marcheco-Teruel et al., 2014, p. 1) is evident in their history knowledge as the study refers to taino farmers who spoke a separate language also totaling ninety percent of the native population of Cuba at the time of the first European contact. As in most DNA studies of the Caribbean natives the deficiency is not within the biological results but in their misconception of history. In (Marcheco-Teruel et al., 2014) they provide the following conclusion, "With regard to the contributions of Native Americans, a clear pattern is also present, with higher average contributions in the eastern provinces, particularly Granma (15\%), Las Tunas $(12 \%)$ and Holguín (12\%) than in the western provinces. (...) The average of European, African and Native American ancestry in those who report themselves as "white" was $86 \%, 6.7 \%$ and $7.8 \%$, in those who 
Randle Sloan Torano, Adv. J Social Sci.; Vol. 7, Issue 1, pp: 14-26, 2020

report themselves as "mestizo" $63.8 \%, 25.5 \%$ and 10.7\%, and in those self-reports to be "black" 29\%, $65.5 \%, 5.5 \%$."

Some may argue that a mixed race or mestizo biological ancestry falls too far from the original native blood to stand for native ancestry (Gonzales et al., 1976). Yet, (José de la Luz y Caballero; Jose María Zayas; Alfredo Zayas y Alfonso; José Fornaris; El Cucalambé; Baron M. Emile Nau; José Joaquín Pérez; the Tejera family) seem to say, that they own by birth-rights as children of their homelands what was handed through the natural evolution of their ancestors: what Tejera refers to as; a bouquet of quisqueyan flowers, and Fornaris as the siboneya race.

\section{Conclusion}

This study discussed historical periods of Caribbean natives since discovery to grasp why a terminological standardization was an effective option to fill a complex space by a community of scholars since the nineteenth century. The study also pointed the complexities of pre-contact native diversity absorbing miscegenation which lead to a Caribbean native biological evolution. We addressed such misunderstandings by presenting a terminological market trend which facilitated a standardized native rather than the independent tribal nations that coexisted throughout the islands. When that coexistence is the root of a Caribbean native biological evolution and survival. The present results of DNA samples link the current Caribbean populations to a native ancestry which is also misinterpreted if interconnected to the taino terminological standardization. Yet, the importance is wide-ranging as it helps to understand ancestry as evolved from the demographics of pre-contact settlements. Considering that pre-Columbian native settlements in Cuba and the Dominican Republic were in the dozens the importance rests in the lack of terms for each tribe and the lack of understanding of each nation and its's legacy. This study navigated across Cuba, Dominican Republic, Florida and beyond to further understand Native American regions. We found that geographical ecosystems and heroes influenced native tribal names as bands, tribes and nations selected denominations. In linguistics we found that our simple samples Gua and Hui are common prefixes identified across ancient American languages linking a human diaspora across geographical independent regions adding dimension to the mystery. When we add-in common linguistic factors to the enormity of original native settlements, and DNA results, we can grasp the magnitude of native Caribbean diversity and the dangers of a terminological standardization. The worst-case scenario is how a standardized terminology forecloses natives' diversity and independence when nativists are likely to benefit from a Caribbean native biological evolution in the long term. It is unimaginable that an academic science intended for identifying and classifying material culture in time would become a real ancestor to millions of people.

\section{Competing Interest}

Author declared that no conflicts of interest exist.

\section{How to Cite this Article:}

Sloan-Torano, R. (2020). Notes on the Native History of Cuba and the Dominican Republic. Advanced Journal of Social Science, 7(1), 14-26. doi: 10.21467/ajss.7.1.14-26

\section{References}

Abbad y Lasierra, Fray Iñigo. (1866). Historia, Geografía Civil y Natural de La Isla de Puerto Rico. Nueva Edición, anotada en la parte histórica y continuada en la estadística y económica. Por José Julián de Acosta y Calbo. Puerto Rico, Imprenta y Librería de Acosta.

Acosta Samper, Soledad. (1883). Biografías de hombres ilustres ó notables, relativas á la época del descubrimiento, conquista y colonización de la parte de América denominada actualmente EE. UU. de Colombia. Bogotá: La Luz.

Alegría, R E. (1978). Apuntes en torno a la mitología de los indios taínos de las Antillas Mayores y sus orígenes suramericanos. Centro de Estudios Avanzados de Puerto Rico y el Caribe, Museo del Hombre Dominicano.

Alegría, Ricardo, and N. B Nicholson. (1955). The Archaic Tradition in Puerto Rico. American Antiquities. 21(2), pp113-131

Arrom, José Juan. (1967). El mundo mítico de los taínos: Notas sobre el Ser Supremo. Thesarus,1(3) pp. 378-93.

Bachiller y Morales, A. (1883). Cuba primitiva. Origen, lenguas, tradiciones e historia de los indios de las Antillas Mayores y Lacayas. 2nd ed. Cuba: Librería de Miguel de Villa.

Bernáldez, Andrés. (1870). Historia de Los Reyes Católicos, D. Fernando y Doña Isabel. Imprenta que fue de D. José María Geofrin. Vol. 1. España. 
Notes on the Native History of Cuba and the Dominican Republic

Boas, Franz. (1920). The Classification of American Languages. American Anthropologist, 22(4), pp.367- 376.

Brinton, D G. (1891). The American Race: A Linguistic Classification and Ethnographic Description of the Native Tribes of North and South America. New York: NDC Hodges.

Brinton, Daniel Garrison. (1871). The Arawack Language of Guiana in Its and Ethnological Relations. American Philosophical Society Transaction, no. 14:427-44.: 427-43.

Bolton, H.E. (1921). The Spanish borderlands: a chronicle of old Florida and the Southwest (Vol. \#23). New Haven: Yale University; Toronto: Glasgow, Brook.

Bourne, E.G. (1906). Columbus, Ramon Pane and the Beginnings of American Anthropology. American Antiquarian Society.

Burley, D. V., Woodward, R. P., Henry, S., \& Conolley, I. C. (2017). Jamaican Taino Settlement Configuration at the Time of Christopher Columbus. Latin American Antiquity, 28(3), 337-352. https://doi.org/10.1017/laq.2017.14

Cassá, Roberto. (1974). Los Tainos de la Española. DR

Coll y Tosté, Cayetano. (1907). Prehistoria de Puerto Rico. Puerto Rico: Tip. San Juan boletín Mercantil.

Colón, Fernando. (1749) "La historia de D." Fernando Colon en la cual se da particular y

verdadera relación de la vida y hechos de el almirante D. Christoval Colón su padre y del descubrimiento de las indias occidentales llamadas Nuevo Mundo. Madrid.

Colón, Hernando. (1946). Los cuatro viajes del almirante y su testamento. Cuarta edición. Edición Austral 633. Madrid: Repasa Calpe.

Columbus, C, and R H Major. (1870). Select Letters of Christopher Columbus: With Other Original Documents, Relating to His Four Voyages to the New World. 2nd ed. Vol. 43. UK: Hakluyt Society.

Columbus, Christopher. (1893). Christopher Columbus; His Own Book of Privileges. Editor Benjamin Franklin Stevens. London: B F Stevens.

Columbus, Christopher, and Bartolome de las Casas. (1827). Personal Narrative of the First Voyage of Columbus to America: From a Manuscript Recently Discovered in Spain. Translated by Samuel Kettell. Wait, Greene and Co.

Casas, Bartolomé de las. (1875). Historia de la Indias. Tomo 1. Madrid.

Casas, Bartolomé de las. (2009). Brevísima Relación de La Destrucción de Las Indias. Editor Andre Saint-Lu. Madrid: Ediciones Catedra.

Douay, León. (1891). Études Étymologiques Sur L'Antiquité Américaine. J. Maisonneuve, Paris.

Fernández de Navarrete, Martin. (1941). Viajes de Américo Vespucio. España: Espasa Calpe.

Fernández de Navarrete, Martin. (1946). Primer Viaje de Colón. España: Espasa Calpe.

Fernández de Oviedo y Valdés, Gonzalo. (1851). Historia General de la Indias. Editor José Amador de los Rios. Vol. 1, 2, 3, 4. $4 \quad$ vols. Madrid, España: Casa de la Real Academia de la Historia.

Fewkes, Jesse Walter. (1907). The Aborigines of Porto Rico and Neighboring Islands. US Gov. Print. Off.

Gordon, T F. (1831) History of the Spanish Discoveries in America. Philadelphia. 2 vols.

Goulaine de Laudonnière, René de., Martin Basanier. (1586). L'Histoire notable de la Floride située es Indes occidentales ... mise en lumière par M. Basanier. Paris, G Auvray.

Harrington, M R. (1921). Cuba Before Columbus. (ed) F W Hodges. New York Museum of the American Indian. Vol. II. 2 vols. NY: Heye Foundation.

Herreras, Antonio. (1730). Descripción [de] las Indias Occidentales. España.

Hulme, Peter. (1986a). Colonial Encounters: Europe and the Native Caribbean, 1492-1797. Methuen. https://doi.org/10.2307/2541613

Hulme, Peter. (1993). Making Sense of the Native Caribbean. NWIG: New West Indian Guide/Nieuwe West-Indische Gids 67 (3/4): 189220. https://doi.org/10.1163/13822373-90002665

Lalueza-Fox, C, F Calderon, F Calafell, B Morera, and J Bertrnpetit. (2001). MtDNA from Extinct Tainos and the Peopling of the Caribbean. Annals of Human Genetics. Mar 1;65(2):137-51. https://doi.org/10.1046/j.1469-1809.2001.6520137.x

Loveman, Mara, and Jeronimo O Muniz. 2007 How Puerto Rico Became White: Boundary Dynamics and Intercensus Racial Reclassification. American Sociological Review 72.6: 915-39.

Lyon, E. (1973). The adelantamiento of Florida: 1565-1568 (Doctoral dissertation, University of Florida).

Marcheco-Teruel, B. (2016). Cáncer de mama en Cuba: conocer mejor los factores de riesgo en pos de estrategias más eficaces de prevención. Cubana Genet Comunit, 10(3), pp.5-7. https://doi.org/10.26820/recimundo/2.(4).octubre.2018.270-297

Mártir Anglería, P M. (1892). Fuentes Históricas Sobre Colón y América: Tomo III. Vol. III. IV. Madrid: Imprenta de la S.E. de San Francisco de Sales.

Mártir Anglería, P M. (1944). Décadas del Nuevo Mundo. Buenos Aires: Editorial Bajel.

Mártir Anglería, P M. (1912). The Eight Decades of Peter Martyr D’Angleria. Francis Augustus MacNutt. Vol. 1. 2 vols. NY, London.

Matson, W. B. (2016). Crazy Horse: The Lakota Warrior's Life \& Legacy. Gibbs Smith.

Morales Otero, Pablo. (1945). Nuestros Problemas. 1st ed. San Juan.

Morejón, J. L. (2018). From the Areíto to the Cordon: indigenous healing dances. Revista Brasileira de Estudos da Presença, 8(3), 563-591. https://doi.org/10.1590/2237-266069826

Muñoz, Juan Bautista. (1780). Historia del Nuevo Mundo. Vol. 1. Madrid: La Viuda de Ibarra.

Olsen, Julius E, and Edward Gaylord Bourne. (1906). The Northmen, Columbus, and Cabot, 985-1503. US: Charles Scribner sons.

Ortiz, Fernando. (1940). Los factores humanos de la cubanidad (pp. 187-207). Impreso por Molina y cia.

Ostapkowicz, J. (2018). To produce "a pleasing effect": Taíno shell and stone cibas and Spanish cuentas in the early colonial Caribbean. BEADS: Journal of the Society of Bead Researchers, 30.

Ozuna, A. (2018). Rebellion and Anti-colonial Struggle in Hispaniola: From Indigenous Agitators to African Rebels. Journal of Pan African Studies, 11(7), 77-96.

Pané, Ramon. (1988). Relación acerca de las antigüedades de los indios: el primer tratado escrito en América. Edited by José Juan Arrom. 3ra edicion Vol. 5. Siglo XXI.

Pané, Ramon. (1999). An Account of the Antiquities of the Indians. Editor Juan José Arrom. Translated by Susan C Criswold. NC \& London: Duke University Press.

Peschel, Oscar. (1876). The Races of Man, and Their Geographical Distribution. HS King \& Company. 
Randle Sloan Torano, Adv. J Social Sci.; Vol. 7, Issue 1, pp: 14-26, 2020

Pichardo, Esteban. (1836). Diccionario provincial de voces cubanas. Imprenta Real Marina.

Rafinesque, C S. (1836). A Life of Travels and Researches in North America and South Europe: Or Outlines or Life, Travels and Researches or C.S. Rafinesque. Philadelphia: C S Rafinesque.

Rafinesque, C S. (1836). The American Nations or, Outlines of Their General History, Ancient and Modern Nations of North and South America. Annals. Philadelphia: C S Rafinesque.

Rodríguez Morel, Genaro. Ed. (2013). Historia General del Pueblo Dominicano. 2da ed. Vol. I. VI vols. Códice. Italia: Academia Dominicana de la Historia.

Rouse, I. (1992). The Tainos Rise and Decline of the People Who Greeted Columbus. Yale University Press. Schroeder et al, Hannes. https://doi.org/10.1086/ahr/99.1.332

Swanton, J.R. (1905). The social organization of American tribes. American Anthropologist, 7(4), pp.663-673.

Sloan Toraño, Randle. (2011) Labradores y Desbandados 1898. 2nd ed. US.

Sloan Toraño, Randle. (2018) Terms and Terminology Conflicts of Social Quandaries Engendered by the Taino Native Fixation a Cultural Crisis Analytical Study in Caribbean Contemporary History. Doi 10.5281/zenodo.253031

Sloan Toraño, Randle. (2019) Caribbean History and Heritage Crisis Resulting from Generic Standardization and Substitution of the Native Boriqueños, Boriquans or Boricuas of Puerto Rico Subsequent to Suspicious Taino Research. doi 10.5281/zenodo.2578260

Stahl, Agustín. (1889). Los Indios Borinqueños. Imprenta y Librería de Acosta. Puerto Rico.

Tapia y Rivera, Alejandro. (1854). Biblioteca histórica de Puerto Rico. Imp. de Márquez.

Taylor, D. \& I Rouse. (1955). Linguistic and archeological time depth in the West Indies. International Journal of American Linguistics, 21(2), pp.105-115. https://doi.org/10.1086/464319

Tejera, Emilio. (1977). Indigenismos. Vol. 1 \& 2. 2 vols. República Dominicana: Editora Santo Domingo.

Tracy, O. (2018). "Rise Up through the Words" Postcolonial Haitian Uncoverings of Anacaona. Journal of Haitian Studies, 24(1), 101-126. https://doi.org/10.1353/jhs.2018.0004

Martius Karl Friedrich Philipp von. (1867). Etnographie un Sprachenkunde Amerika's zumal Brasiliens. Vol. II. Leipsig: Friedrich Fleicher.

Veloz Maggiolo, M. (1997). The daily life of the Taino people. Taino: Pre-Columbian Art and Culture from the Caribbean, Monacelli Press, New York, pp.34-45.

Zayas y Alfonso, Alfredo. (1914). Lexicografía Antillana. Imprenta siglo XX A. Miranda. Cuba.

Publish your research article in AIJR journals-

* Online Submission and Tracking

* Peer-Reviewed

* Rapid decision

* Immediate Publication after acceptance

- Articles freely available online

- Retain full copyright of your article.

Submit your article at journals.aijr.in
Publish your books with AIJR publisher-

* Publish with ISBN and DOI.

* Publish Thesis/Dissertation as Monograph.

* Publish Book Monograph.

* Publish Edited Volume/ Book.

- Publish Conference Proceedings

- Retain full copyright of your books.

Submit your manuscript at books.aijr.org 